\title{
Development of Contextual Learning Models in Improving the Multiple Intelligence of Early Childhood
}

\author{
Sariana Marbun ${ }^{1 *}$, Peny Husna Handayani ${ }^{2}$, Jasper Simanjuntak ${ }^{3}$, Wan Nova Listia ${ }^{4}$ \\ ${ }^{1-4)}$ Faculty of Education, Universitas Negeri Medan \\ *sariana.marbun1961@gmail.com
}

\begin{abstract}
This study aims to describe the process of developing a contextual learning model in improving multiple intelligence in early childhood, as well as describing a valid contextual learning model that can be used by teachers to improve multiple intelligence in early childhood. The development of the Context Learning Model is carried out through Research Development (R\&D) with the Borg and Gall Model which is grouped into 4 stages, namely, the preliminary stage, planning and development, evaluation and revision, and dissemination. The instrument used was a validation sheet to test the feasibility of the mode and the response sheet to be filled out by the teacher. The contextual learning model that can be used to improve the multiple intelligence of early childhood is validated by one expert in Educational Technology and one Early Childhood Education Expert and shows that the learning model is very valid with an average value of 5.02. Teacher responses showed good results, as many as $75 \%$ of teachers stated very agree with this learning model, the remaining $25 \%$ agreed. The results of the study recommend the need for early childhood education teachers to apply the Contextual Learning Model in developing the Early Childhood multiple Intelligence.
\end{abstract}

Keywords: contextual learning model, multiple intelligence, early childhood

\section{Introduction}

Education is a process to develop all the potential possessed by students, so that the potential develops optimally. Every individual who learns has different abilities and intelligence. Therefore, every formal educational institution through which children should be able to equip a number of knowledge, skills and attitudes so that the potential and other intelligence possessed by children develop well. Hermawan et al, [1] suggested that "The quality of human resources that must be produced in education in the future is humans who have three main characteristics, namely: 1) mastering science and technology; 2) have creativity, and 3) have social solidarity. Furthermore, Lwin May [2] argues that academic success alone is not a good indicator of one's success in life, and to deliver children to success in life and be prepared for the future, we must develop a level of intelligence in various aspects. Gardner [3] believes that all humans have not only one intelligence (intelligence) but group abilities. Some of these opinions conclude that each individual has some intelligence (plural intelligences) which must be developed in line with the development of other aspects of development that must be developed in accordance with the level of achievement of the child's development.

Multiple intelligences in each individual can be developed since the child is in Early Childhood Education, especially in kindergarten (ages 4-6 years). Early Childhood Education has a very important role in preparing children to enter higher education. The importance of 
children being educated from an early age because at this time all aspects of child development (religious and moral values, cognitive, socio-emotional, language, physicalmotor, and art) experience very rapid developmental growth, so that providing stimulus, mental development, moral, and the right spiritual and the provision of healthy and nutritious food to children will be the foundation for children in facing their growth and development in the future. In addition to stimulating aspects of child development, educators in early childhood education should be able to design learning that is able to develop other intelligence possessed by children, because each child has a different intelligence. One of the recommended learning models for stimulating plural children's intelligence is Contextual Learning. Sanjaya [4] argues Contextual learning emphasizes the process of full student involvement to be able to find material or learning that is oriented to the process of direct experience.

Based on several research and observation results, as well as interviews that have been conducted with $P A U D$ / TK teachers in Medan City and teachers in North Sumatra Province, in general teachers lack understanding about the application of contextual learning models, and efforts to develop plural intelligence in early childhood. In general, teachers teach early childhood by applying the lecture method, questions and answers, and assignments by doing worksheets that have been prepared by the school, especially for reading, writing and arithmetic. Teachers are less teaching children to construct children's knowledge, less inviting children to find something (inquiry) for example through experiments, simulating, utilizing the environment for learning. Likewise in conducting assessments, teachers only tend to judge children from the results of work done by children, lack understanding in doing assessments during the child's learning process, let alone convey the results of teacher observations of children's learning processes, especially related to the plural intelligence of children. Contextual learning is one of the recommended learning models in the application of the 2013 Early Childhood Education Curriculum.

Studies on plural intelligences have been put forward by many experts, including Charles Spearmen with his theory General Intelligence, Raymond Cattel and John Horn with his theory of Fluid and Crystalized Intelligence, and Stenberg with Triarchic Intelligence theory, and subsequently the Goleman intelligence expert with Emotional Intelligence theory, and subsequently the Fluid and Crystalized Intelligence theory, and Stenberg with the Triarchic Intellegence theory, and subsequently the Goleman intelligence expert with the Emotional Intellegence theory, and later Gardner with the theory of Multiple Intelligence. Furthermore, Armstrong adds one more theory which is widely studied, namely from Guillford with Structure Intelligence theory. Each expert put forward a definition of intelligence, and overall states that intelligence is expressed as a potential that needs to be developed in every human being. Likewise argues, intelligence is the ability to do something useful in society in the surrounding environment. While Gottfredson [5] argues that "intelligence is a general mental ability, and among others as the ability to study, plan, solve problems, think abstractly, express ideas, learn quickly and learn from experience". From some of the opinions above assert that intelligence as an ability. Ability is a power or strength as a result of learning that can be known. This ability functions to solve, manage, plan, solve problems, think abstractly, express ideas all of which are through the learning process. Multiple intelligences are all the powers or abilities that can be developed through learning.

Multiple intelligences that can be developed in children according to Gardner [6] include: (1) Linguistic intelligence, namely, the ability to use language to express ideas about themselves and understand others and to learn new words or other languages; (2) Mathematical Logic Intelligence is a person's ability to think inductively and deductively, 
think according to the rules of logic, understand and tend to like the activity of analyzing patterns of numbers, and solving problems using thinking skills, (3) Spatial-visual intelligence of one's ability to read maps and drawings, imagine a room or object does not exist and make certain shapes of objects even though the objects do not exist and make certain shapes of objects, for example blocks; (4) Kinesthetic intelligence, which is the ability of a person to actively use parts or his entire body to communicate and solve various problems, for example someone who excels in one sport or someone who is good at dancing, etc; (5) Musical intelligence, which is the ability of a person sensitive to the nonverbal sounds that surround him, including in this case are the tone and rhythm; (6) Interpersonal intelligence, which is the ability of children to play together, concentrate on dramatic games, play by decorating themselves (dressing up), showing interest in knowing about sex differences, liking role play, maintaining friendship, and siding with someone or something; (7) Intrapersonal intelligence, which is the ability: to know oneself, compare oneself and others, understand this world from their own perspective, enjoy being together with others, direct themselves with more control, begin to increase awareness of reality, and leave fear; (8) Naturalist intelligence, which is the desire of children to collect plants and plants that are around, linger outside the home, and show good ability to discriminate between different animals and plants and have the ability to identify the objects obtained.

The overall intelligence stated above can be developed through a contextual learning model. Contextual learning is teaching that allows students to strengthen, expand, and apply their academic knowledge and skills in a variety of settings in school and outside of school in order to solve real-world problems or simulated problems. The contextual learning model is based on the results of the research of John Dewey which concluded that students will learn well if what is learned is related to what is known and to the activities or events that occur around it. Some theories that underlie contextual learning, according to Suryanti [7] : a) Knowledge Based Constructional, which emphasizes the importance of children's ability to build their own knowledge through active involvement in learning; b) Efford-based Learning, c) socialization; d) situated learning; e) distributed learning. Priansa [8] argues that "Contextual Learning encourages students to make connections between the knowledge they have and their application in daily life, so that students engage in meaningful activities". With the application of contextual learning children will be actively involved in learning, so that it will provide opportunities for the development of multiple intelligences that children have in addition to aspects of development that must be developed.

Contextual Teaching and Learning is a learning concept that helps teachers link material taught with real-world situations and encourage students to make connections between the knowledge they have and their application in daily life, involving seven main components namely constructivism, asking questions, inquiry, learning communities, modeling, reflection and authentic assessment [9]. By applying every component of the contextual learning model appropriately in Early Childhood learning, it allows the child's multiple intelligences to develop properly, although not every day these components must be done. For example, when teachers apply the constructivist component, ask questions, and reflexes will practice linguistic, spatial intelligence. with inquiry will train the intelligence of mathematical logic, and naturalists, with modeling children will train kinesthetic, musical intelligence, and with the learning community will train intrapersonal, and interpersonal intelligence [10]. The success of the teacher in applying the contextual learning model in developing the plural intelligence of early childhood, is highly dependent on the teacher's ability to design learning activities, and the teacher's skills in utilizing the media and learning resources in learning. 


\section{Research Method}

The Research and Development Model carried out refers to the Borg and Gall model which includes 10 steps and is grouped into 4 stages, namely:

1) Preliminary stage, the activities carried out are, reviewing theories, concepts, and findings. research findings, and discussions with Educational Technology and Early Childhood Education experts, analyzing the criteria for developing learning models for the development of plural early childhood intelligence and conducting field surveys to obtain data on: teacher perceptions about the implementation of contextual learning, plural intelligence development in early childhood, and analysis of learning courses Approaches and Learning Strategies in PG PAUD Study Program;

2) Planning and Development, the activities carried out are: designing the Development of Contextual Learning Models and plural intelligence instruments of early childhood especially Kindergarten children (ages 5-6 years), Validating Learning Models, preparing RPPH for the application of contextual learning models, and conducted a phase I trial of 5 children;

3) Model Evaluation, validation and Revision; The activities carried out at this stage are formative evaluations aimed at gathering data on the strengths and weaknesses of contextual learning that have been implemented in kindergarten children in stage I (limited trial I), reviews and validation of contextual learning models for trials phase II, conducted a phase II trial conducted on 15 children of TK Pembina 1 Medan, and analyzed the data. The results of the phase II trial were to find out the effectiveness of the contextual learning model in developing plural intelligence in early childhood (kindergarten). The results of the phase II data analysis will be the final test of the model, and will be the model that will be implemented in the next stage.

4) Dissemination and Implementation, activities carried out to disseminate a limited contextual learning model in developing the plural intelligence of early childhood in kindergarten teachers in the city of Medan to be implemented.

Research instruments and data analysis techniques used are:

Validation Sheet for Contextual Learning Models in improving Early Childhood

$$
R=\frac{\sum_{i=1}^{n} V_{i}}{n}
$$

Multiple Intelligence, and data analysis techniques used are:

Table 1. Learning Model Validation Instrument Grid

\begin{tabular}{|c|c|c|}
\hline No & Indicator & Amount \\
\hline 1 & Compliance with PAUD goals & 6 \\
\hline 2 & $\begin{array}{l}\text { The suitability of the model in developing multiple intelligence in early } \\
\text { childhood }\end{array}$ & 1 \\
\hline 3 & Conformity with the scope of material / themes in Early Childhood Education & 2 \\
\hline 4 & Conformity with the form of learning activities & 4 \\
\hline 5 & Conformity to the type of game in Early Childhood Education & 3 \\
\hline 6 & $\begin{array}{l}\text { Compatibility with media, tools and learning resources (inside and outside the } \\
\text { classroom) }\end{array}$ & 3 \\
\hline 7 & Conformity with teacher's ability & 2 \\
\hline
\end{tabular}


Response Sheet for early childhood education teachers about the Context Learning Model which is used to determine the effectiveness of the teacher in applying the contextual learning model, especially in developing the multiple intelligence of early childhood, is analyzed by percentage techniques. The lattice instruments used are as follows:

Table 2. Instrument Grid Teacher's Response to Learning Models

\begin{tabular}{clc}
\hline No & Indicator & Amount \\
\hline 1 & Interesting and fun learning activities & 1 \\
2 & Effectively develops all aspects of child development & 1 \\
3 & Children's participation and activities are very good & 1 \\
4 & Encourage children to ask questions and express opinions & 1 \\
5 & The learning process fosters children's curiosity & 1 \\
6 & The learning process supports the development of children's talents & 1 \\
7 & The learning model is simple and easy to use & 1 \\
8 & Make it easier for teachers to apply a scientific approach & 1 \\
9 & Make it easier for teachers to manage classes & 1 \\
10 & Make it easier for teachers to achieve learning goals & 1 \\
11 & Make it easier for teachers to make assessments & 1 \\
12 & Motivating teachers using audio-visual media & 1 \\
\hline
\end{tabular}

\section{Results and Discussion}

\section{Preliminary Stage}

Analysis conducted through theoretical and practical studies suggested in the early childhood education curriculum that learning in early childhood should be done contextually. One of the principles of developing learning materials and playing early childhood in accordance with children's daily lives, all teachers should be able to implement contextual learning models. Optimizing contextual learning will help teachers develop all aspects of child development and develop plural intelligence in early childhood. The important things that teachers need to consider in developing a contextual learning model in PAUD are, (a) theoretical rationales compiled by their creators or developers; (b) The foundation of thought about what and how students learn (learning objectives to be achieved); (c) The teaching behavior needed for the model to be implemented successfully; (d) The environment needed to achieve the learning objectives.

Learning in early childhood education is the process of interaction between educators and children through play activities in a safe and enjoyable learning environment by using various learning resources. The learning approach used is a scientific approach that includes a series of processes of observing, reasoning, and communicating. The whole process is carried out using all the senses as well as various sources and learning media. With the concept of learning in early childhood education, it appears that learning is not only to stimulate six aspects of child development, but is able to develop multiple children's intelligence, and contextual learning models are very possible to be applied by teachers, because some of the principles of contextual learning models are very relevant with the approaches and principles of learning that exist in early childhood education. 


\section{Planning and Development Stage}

From the analysis of theoretical studies on contextual learning models and expert input on learning, that contextual learning models can be applied when the teacher teaches what themes are in early childhood education. The steps of the contextual learning model that are applied in early childhood learning, especially in the effort to develop multiple children's intelligence are as follows:

Table 3. Steps in the Contextual Learning Model in Early Childhood Education

\begin{tabular}{|c|c|c|}
\hline No & Phase & Teacher's Role \\
\hline 1 & $\begin{array}{l}\text { Preparation } \\
\text { phase }\end{array}$ & $\begin{array}{l}\text { a. Prepare materials, media, tools and learning resources that will be } \\
\text { used in learning } \\
\text { b. Arrange child seats in accordance with the form of activities (groups, } \\
\text { centers) } \\
\text { c. Prepare child worksheets } \\
\text { d. Marching in the school yard doing movements and songs as well as } \\
\text { physical fitness exercises }\end{array}$ \\
\hline 2 & $\begin{array}{l}\text { Preliminary } \\
\text { Phase }\end{array}$ & $\begin{array}{l}\text { a. Invite children to pray before learning, short prayers that are used } \\
\text { daily, singing good morning, songs about respecting teachers, } \\
\text { parents, and friends. } \\
\text { b. Talk about the child's morning activities with the family, until the } \\
\text { child prepares to come to school. } \\
\text { c. Delivering themes / sub-themes to be studied } \\
\text { d. Building children's thoughts about sub-themes to be studied } \\
\text { (constructivism), for example doing Q\&A about the material to be } \\
\text { learned. } \\
\text { e. Apperception } \\
\text { f. Deliver the learning objectives to be achieved by children. } \\
\text { g. Inviting children to sing by doing movements in accordance with the } \\
\text { sub themes to be studied }\end{array}$ \\
\hline 3 & $\begin{array}{l}\text { Core Activity } \\
\text { Phase }\end{array}$ & $\begin{array}{l}\text { a. Asking children to observe pictures / videos / objects directly (real) } \\
\text { or bring children to the surrounding environment in accordance with } \\
\text { the sub themes (material) being studied } \\
\text { b. Ask questions about the material and relate it to children's daily lives. } \\
\text { c. Submitting problems (according to the material) found by children in } \\
\text { daily life, and asking children to determine and suggest alternative } \\
\text { answers in overcoming these problems (for example, why should } \\
\text { care for plants / pets? How to treat them; why should work together / } \\
\text { cooperate and so. } \\
\text { d. Invite children to sing and move (together or individually) in } \\
\text { accordance with the theme / material } \\
\text { e. Perform gross motor movements, such as running, jumping, } \\
\text { throwing, and so on according to the material. } \\
\text { f. Asking children to tell stories according to their experiences } \\
\text { (according to the material) and when the teacher tells the story, } \\
\text { asking children to mention the characters in the story and asking } \\
\text { children to repeat the contents of the teacher's story in turns } \\
\text { g. As a group of children doing inquiry activities, experiments, } \\
\text { demonstrations, role playing and doing projects (adjusted objectives } \\
\text { and learning materials) } \\
\text { h. Children are asked to do activities, count, write, draw freely, color } \\
\text { draw according to learning material }\end{array}$ \\
\hline
\end{tabular}




\begin{tabular}{ll}
\hline No Phase & Teacher's Role \\
\hline i. & $\begin{array}{l}\text { As a group children play building with educational toys (blocks, } \\
\text { plasticine, glassware, etc.) } \\
\text { Asking children to communicate the work they have made and other } \\
\text { children responding to the work of their friends }\end{array}$ \\
& k. $\begin{array}{l}\text { Invite the child to return the game equipment to its original place } \\
\text { 1. }\end{array}$ \\
& Familiarize the children clean the children's former dining table and \\
tidy up the former place to eat children.
\end{tabular}

The contextual learning model that can be used to increase the intelligence of plural early childhood children is validated by one expert in Education Technology and one expert in Early Childhood Education. Data analysis shows that the learning model is very valid and can be tested. The results of the validation of the learning model can be seen in the following table:

Table 4. Validation Test Results for Contextual Learning Models

\begin{tabular}{clcl}
\hline No & Learning Model Aspects & Score & Criteria \\
\hline 1 & Compliance with early childhood education goals & 7,2 & Very Valid \\
2 & $\begin{array}{l}\text { Conformity with the development of plural intelligence } \\
\text { Early Childhood }\end{array}$ & 5 & Very Valid \\
3 & $\begin{array}{l}\text { Conformity with the scope of material / themes in Early } \\
\text { Childhood Education }\end{array}$ & Valid \\
4 & Carried out in the form and steps of learning activities & 4,75 & Very Valid \\
5 & $\begin{array}{l}\text { Conformity to the type of game in Early Childhood } \\
\text { Education }\end{array}$ & 4,15 & Valid \\
6 & $\begin{array}{l}\text { Use of media, learning tools (in the classroom and outside } \\
\text { the classroom), and learning resources / environment }\end{array}$ & 4,8 & Very Valid \\
& $\begin{array}{l}\text { around the school } \\
7\end{array}$ & 5 & Teacher's Ability \\
\hline & Average & $\mathbf{5 , 0 2}$ & Very Valid \\
\hline
\end{tabular}

\section{Evaluation, Validation and Model Revision Stage}

The results of the Phase 1 learning model trial found that the application of the contextual learning model was able to improve the kind of plural intelligence of kindergarten children even though only at the level of Developing as Expected. Based on the results of evaluations of the learning model and plural children's intelligence instruments, it was found that in the children's multiple intelligence instruments there were items that were not appropriate, namely in the Kinesthetic aspects (2 items) and in the Intra Personal Intelligence Aspects (2 items). Points cannot be observed because no children exhibit such behavior. The results of 
discussions with the expert team both stated not to include the item again [11]. In the design of contextual learning models only need to add to the concluding section to do questions to children about the use of all that has been learned in relation to children's daily lives.

To find out the teacher's response to the application of the contextual learning model, particularly in developing the plural intelligence of early childhood / kindergarten, the teacher involved in testing the learning model ( 6 people) was asked to fill in the questionnaire provided. Teacher's response data to the model contextual learning can be seen in the following table:

Table 5. Teachers' Responses to the Implementation of Contextual Learning Models in improving Children's Multiple Intelligences

\begin{tabular}{|c|c|c|c|c|c|c|c|c|c|}
\hline \multirow[b]{2}{*}{ No } & \multirow[b]{2}{*}{ Indicator } & \multicolumn{8}{|c|}{ Assessment criteria /\% } \\
\hline & & SA & $\%$ & $\mathbf{A}$ & $\%$ & DA & $\%$ & VDA & $\%$ \\
\hline 1 & $\begin{array}{l}\text { Interesting and fun learning } \\
\text { activities }\end{array}$ & 6 & 100 & - & - & - & - & - & - \\
\hline 2 & $\begin{array}{l}\text { Effectively develops all } \\
\text { aspects of child development } \\
\text { Children's participation and }\end{array}$ & 4 & 67 & 2 & 34 & - & - & - & - \\
\hline 3 & activities are very good & 6 & 100 & - & - & - & - & - & - \\
\hline 4 & $\begin{array}{l}\text { Encourage children to ask } \\
\text { questions and express } \\
\text { opinions }\end{array}$ & 5 & 83 & 1 & 17 & - & - & - & - \\
\hline 5 & $\begin{array}{l}\text { The learning process fosters } \\
\text { children's curiosity } \\
\text { The learning process supports }\end{array}$ & 5 & 83 & 1 & 17 & - & - & - & - \\
\hline 6 & $\begin{array}{l}\text { the development of children's } \\
\text { talents }\end{array}$ & 6 & 100 & - & - & - & - & - & - \\
\hline 7 & $\begin{array}{l}\text { The learning model is simple } \\
\text { and easy to use }\end{array}$ & 2 & 33 & 4 & 67 & - & - & - & - \\
\hline 8 & apply a scientific approach & 4 & 67 & 2 & 33 & - & - & - & - \\
\hline 9 & $\begin{array}{l}\text { Make it easier for teachers to } \\
\text { manage classes }\end{array}$ & 3 & 50 & 3 & 50 & - & - & - & - \\
\hline 10 & achieve learning goals & 4 & 67 & 2 & 33 & - & - & - & - \\
\hline 11 & $\begin{array}{l}\text { Make it easier for teachers to } \\
\text { make assessments }\end{array}$ & 3 & 50 & 3 & 50 & - & - & - & - \\
\hline 12 & $\begin{array}{l}\text { Motivating teachers using } \\
\text { audio-visual media }\end{array}$ & 6 & 100 & - & - & - & - & - & - \\
\hline & Average & & $75 \%$ & & $25 \%$ & & ) & & \\
\hline
\end{tabular}

The data above shows that the teacher's response turned out to be very positive, because almost all teachers stated that they strongly agreed (SA) and Agree (A) the application of the contextual learning model in kindergarten, and there were no teachers who stated Disagreeing (DA) let alone Very Disagreeing (VDA) on the application of the contextual learning model.

The results of research that have been carried out as a whole starting from describing the procedures for developing contextual learning models, validating the models and instruments of multiple children's intelligence, conducting trials, evaluations and revisions, produce a Guide to the Implementation of Contextual Learning in Early Childhood Education and this 
Guide will help teacher to design context-based learning. Contextual learning can be applied when the teacher teaches any theme to children, and can apply a variety of learning methods, media and educational game tools utilizing a variety of learning resources. Implementation Contextual learning is very relevant to be done in Early Childhood Education, because it is in accordance with the learning principles set out in the 2013 Early Childhood Education Curriculum [12].

\section{Conclusion}

The Development of Contextual Learning Models in improving Early Childhood Multiple Intelligence using the Borg and Gall Research model, is carried out by grouping into 4 stages, namely stages: a) Introduction, with discussions with experts, literature studies, and field surveys about the application of contextual learning models; b) Planning and Development, with activities to design learning models, validation by experts, preparation of multiple intelligence instruments for young children, preparation of daily learning designs and testing model 1 stages; c) Evaluation, Validation, and Revision of the Model, with the activity of analyzing the results of trial 1, validating the revised model to the experts, conducting phase 2 trials, and analyzing the results of the revised model trials; d) Dissemination and Implementation, disseminating research results in the form of teacher guidance in carrying out contextual learning in increasing the multiple intelligence of early childhood.

Contextual Learning Model in increasing the plural intelligence of early childhood which has been validated by 2 experts before testing and data collection. Validation results show an average validation value of 5.02 and categorized as very valid. The application of learning models in early childhood education received a very positive response from teachers, as many as $75 \%$ of the teachers who were respondents stated very agree and as many as $25 \%$ agreed to implement contextual learning in early childhood education to help stimulate and improve children's multiple intelligences.

\section{References}

[1] Hermawan, Asep Henry. (2014), Pengembangan Kurikulum dan Pembelajaran di SD. Tangerang : Universitas Terbuka.

[2] Lwin, May, et al., (2008), How To Multiply Your Child's Intelligance : Cara Mengembangkan Berbagai Komponen Kecerdasan. Jakarta : Penerbit Indeks.

[3] Gardner, Howard. (1999), Intelligences Reframed :Multipe Intelligence for the $21^{\text {st }}$ Century. New York : Basic Books.

[4] Sanjaya, Wina. (2006), Strategi Pembelajaran Berorientasi Standar Proses Pendidikan. Jakarta :Kencana Prenada Media Group.

[5] Elliott, Stephen, et al., (2000), Educational Psychology Effensive Learning. London : McGraw Hill.

[6] Gardner, Howard. (1993), Frames Of Mind The Theory of Multiple Intelligences. New York : Basic Books A Member of The Perseus Books Group.

[7] Sri Milfayetty. (2018), Psikologi Pendidikan. Medan : PPs Unimed.

[8] Priansa, Donni Juni. (2017), Pengembangan Strategi \& Model Pembelajaran. Bandung : Pustaka Setia. 
[9] Setyosari, Punaji. (2013), MetodePenelitian Pendidikan \& Pengembangan. Jakarta :KencanaPrenada Media Group.

[10] Suparman, Atwi. (2012), Desain Instruksional Modern : Panduan Para Pengajar dan Inovator Pendidikan. Jakarta : Penerbit Erlangga.

[11] Uno, Hamzah B. (2011), Model Pembelajaran :Menciptakan Proses BelajarMengajar yang Kreatif dan Efektif. Jakarta : BumiAksara.

[12] Woolfolk, Anita. (2009), Educational Psychology (Active Learning Edition), Yogyakarta: Pustaka Pelajar. 